\title{
A NEW SPECIES OF PHILONOTIS FROM BOLIVIA
}

\section{(MUSCI : BARTRAMIACEAE)}

\author{
Harold Robinson \\ Department of Botany \\ Smithsonian Institution, Washington, D.C., 20560.
}

Specimens of mosses collected by F. J. Hermann in Bolivia in 1972 have proven to contain a few examples of less we11-known entities including the supposedly endemic genera Emythrophylzopsis and Leptopterygynandmum. One of the specimens is a Bartramiaceous moss with some unique details of leaf structure which cannot be matched with any previously known species. The species is easily recognizeable, and it is therefore described here, but it is hoped that fruiting material will be found by future collectors.

The new species has the form of papillosity or prorulosity that is common in Philonotis and related genera in the Bartramiaceae. The general aspect is somewhat like Conostomum, but there is no ranking of leaves as is common in that genus. As far as can be seen, the species falls within the great variation of the genus Philonotis, but ultimate positioning awaits examination of fruiting material.

The precise form of prorulosity in the new species seems to be unique among American members of Philonotis, having papillae at the upper ends of the cells on both the upper and lower surfaces of the leaves. A still more distinctive feature of the species is the rows of cells on the backs of the leaves forming about three ribs on each side of the costa. These ribs of cells on the back of the lamina are only one cell wide below, but become two cells wide near midleaf where they terminate.

The species is named for the collector, Frederick J. Hermann.

PHILONOTIS HERMANNII H. Robinson, sp. nov.

Plantae caespitosae flavo-virides inferne fuscescentes. Caules ca. $1 \mathrm{~cm}$ alti extus aurantiaci. Folia in sicco erecta appressa madido erecto-patentia ovato-lanceolata ca. $1.5 \mathrm{~mm}$ longa et inferne $0.5 \mathrm{~mm}$ lata superne subulata apice anguste pungentia margine anguste recurvata; costa percurrens inferne ca. 45-50 $\mu \mathrm{m}$ lata; laminae in plicis longitudinalibus bistratosae, plicis utrinque ca. 3 inferne uniseriatis superne saepe sensim biseriatis, cellulis alaribus subquadratis vel breviter oblongis ca. 12 um latis, cellulis inferioribus interioribus oblongis ca. 10-12 $\mu \mathrm{m}$ latis et plerumque $22-37 \mu \mathrm{m}$ longis, cellulis superioribus

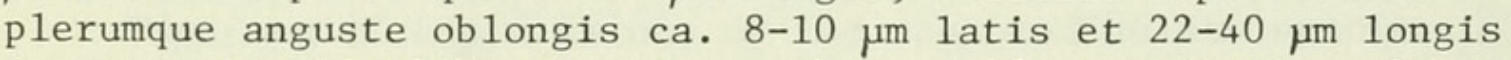
in extremis apicalibus supra et subtus valde prorulosis. Gametangia et sporocarpia ignota. 
TYPE: BOLIVIA: Cochabamba: Vertical face of roadside cut near Liriuni Aguas Termales Hote1, NW slope of Mt. Tunari, alt. ca. $2700 \mathrm{~m}, 28 \mathrm{~km} \mathrm{NW}$. Cochabamba. Dec. 27, 1972. F.J.Hermann 25235 (Holotype, US).
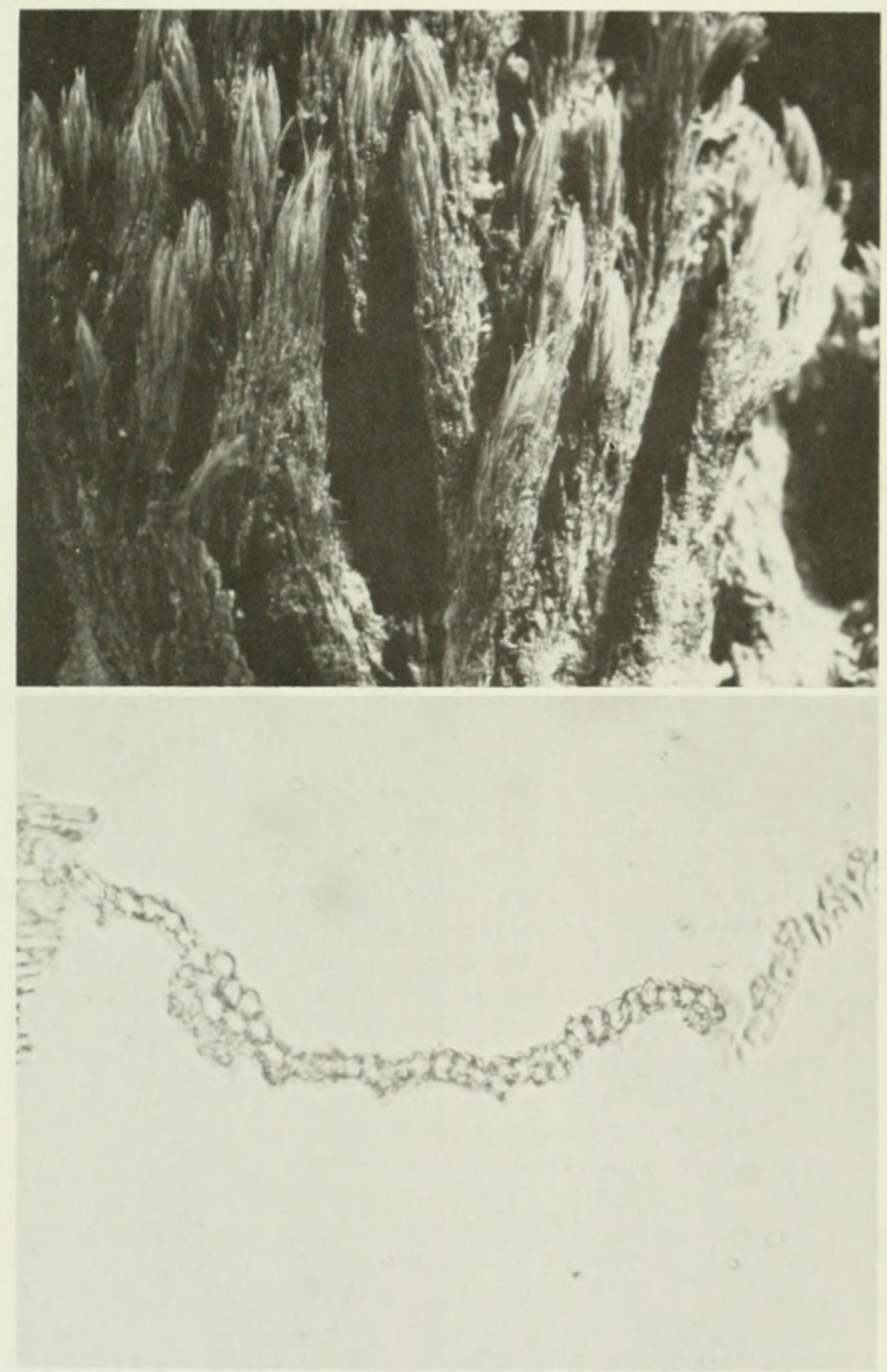

Philonotis hermannii H. Robinson, Holotype, United States National Herbarium. Top. Habit of plant. Bottom. Cross-section of leaf. Photos by Victor E. Krantz, Staff Photographer, National Museum of Natural History. 

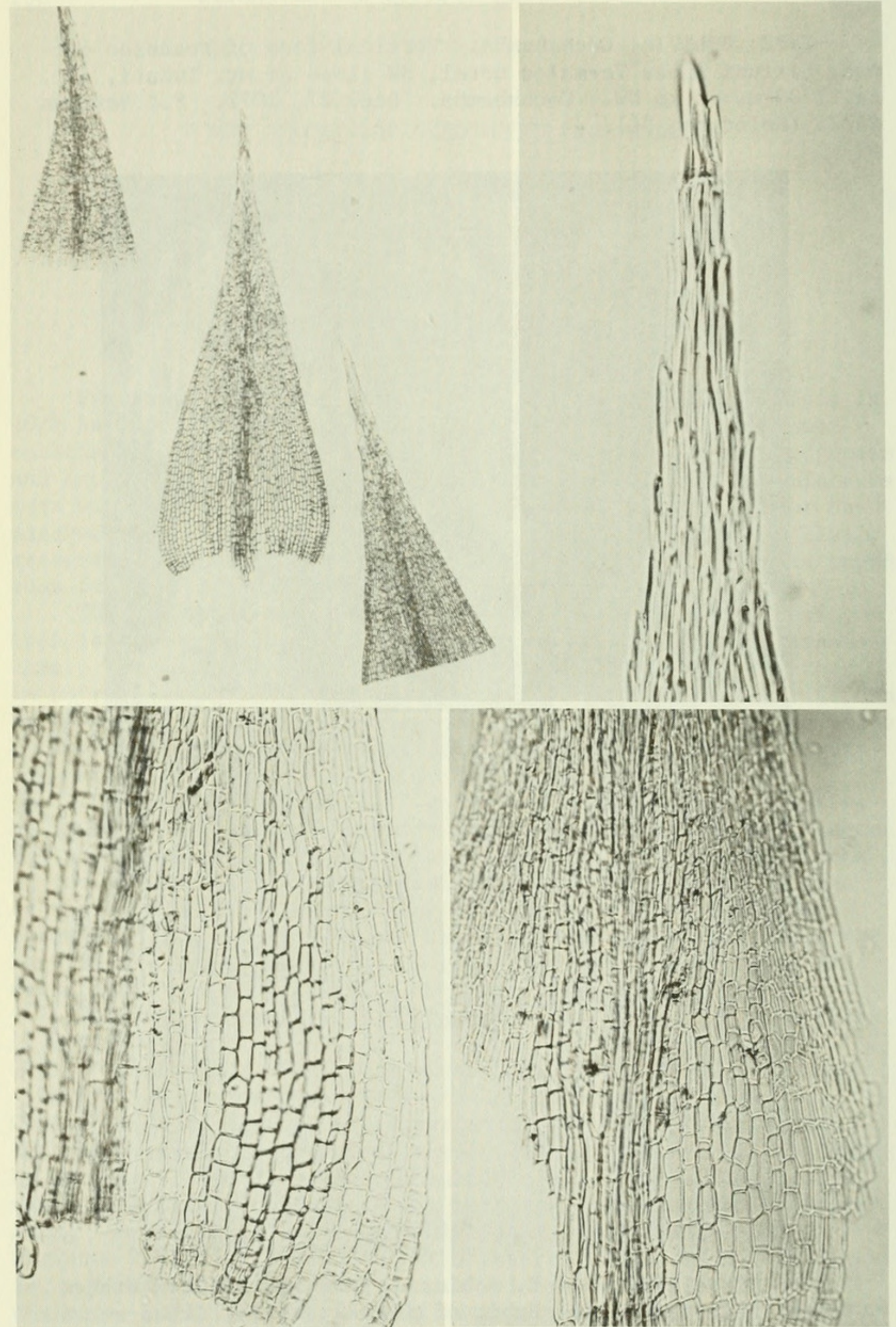

Philonotis hermannii H. Robinson. Top left. Leaves. Top right. Leaf tip showing prorulose cells. Bottom left and right. Lower leaf laminae showing extraplanar rows of cells. 


\section{$2 \mathrm{BHL}$ Biodiversity Heritage Library}

Robinson, Harold Ernest. 1980. "A new species of Philonotis from Bolivia. (Musci: Bartramiaceae)." Phytologia 45, 460-462.

https://doi.org/10.5962/bhl.part.28294.

View This Item Online: https://www.biodiversitylibrary.org/item/48954

DOI: https://doi.org/10.5962/bhl.part.28294

Permalink: https://www.biodiversitylibrary.org/partpdf/28294

\section{Holding Institution}

New York Botanical Garden, LuEsther T. Mertz Library

\section{Sponsored by}

The LuEsther T Mertz Library, the New York Botanical Garden

\section{Copyright \& Reuse}

Copyright Status: In copyright. Digitized with the permission of the rights holder.

Rights Holder: Phytologia

License: http://creativecommons.org/licenses/by-nc-sa/3.0/

Rights: https://biodiversitylibrary.org/permissions

This document was created from content at the Biodiversity Heritage Library, the world's largest open access digital library for biodiversity literature and archives. Visit BHL at https://www.biodiversitylibrary.org. 